\title{
Resistencia a cadmio (Cd) de bacterias endófitas y bacterias rizosféricas aisladas a partir de Oriza sativa en Colombia
}

\section{Cadmium resistance of endophytic bacteria and rizosféricas bacteria isolated from Oriza sativa in Colombia}

\author{
Ayubb T Nataly ${ }^{1}$ Quim, Cerra G Armando ${ }^{1 *}$ Lic, \\ Chamorro A Leonardo ${ }^{2}$ M.Sc, Pérez C Alexander ${ }^{3}$ Ph.D \\ 'Universidad de Sucre, Facultad de Educación y Ciencias, Ciencias Ambientales. \\ 2Universidad de Sucre, Facultad de Ciencias Agropecuarias, Grupo Bioprospección Agropecuaria. \\ ${ }^{3}$ Universidad de Sucre, Facultad de Ciencias Agropecuarias, Grupo Bioprospección Agropecuaria
}

\section{Keywords:}

Rizospheric bacteria; rizosphere; tolerance;

$\mathrm{Cd}$

\section{Abstract}

The present study had as objective to evaluate in vitro the resistance of endophytic bacteria and rizospheric bacteria to different concentrations of Cadmium. This bacteria were isolated fron different tissues of commercial rice varieties and from bacteria isolated from the rhizosphere in rice plantations of the Nechí (Antioquía) and Achí (Bolivar). Plant growth promotion was evaluated in vitro by nitrogen fixation, phosphate solubilization and siderophores production of endophytic bacteria. Of each tissue isolated from rice plants was carried out isolation in culture medium for endophytic bacteria, and the soil samples were serially diluted in peptone water. Each sample was determined the population density by counting in CFU / g of tissue and morphotypes were separated by shape, color, size and appearance in culture media. Significant differences were observed for density population of bacteria with respect to tissue, with higher values in root $\left(4 \times 10^{11} \mathrm{~g} / \mathrm{root}\right)$, followed of the stem $\left(3 \times 10^{10} \mathrm{~g} / \mathrm{etem}\right)$, leaf $\left(5 \times 10^{9}\right.$ $\mathrm{g} /$ leaf), flag leaf $\left(3 \times 10^{9} \mathrm{~g} /\right.$ flag leaf) and with less density in panicle $\left(4 \times 10^{8} \mathrm{~g} /\right.$ panicle). The results of the identification with kit API were confirmed the presence of endophytic bacteria Burkholderia cepaceae and rizospheric bacteria Pseudomona fluorescens With the ability to tolerate different concentrations of $\mathrm{Cd}$, fix nitrogen, solubilize phosphates and produce siderophores.

\section{Resumen}

El presente estudio tuvo como objetivo evaluar in vitro la resistencia de bacterias endófitas y rizosféricas a diferentes concentraciones de Cadmio (Cd). Se evaluó in vitro la promoción de crecimiento vegetal mediante la fijación de nitrógeno, solubilización de fosfato y producción de sideróforos de bacterias endófitas aisladas de diferentes tejidos de variedades de arroz comerciales y de bacterias aisladas de la rizósfera en las plantaciones de arroz de los corregimientos de Nechí (Antioquía) y Achí (Bolívar). Se colectaron muestras de raíz, tallos y hojas de plantas de arroz y de muestras de suelo rizosférico. A cada muestra se les determinó la densidad poblacional por medio de conteo en UFC/ $g$ de tejido y se separaron morfotipos por forma, color, tamaño y apariencia en medios de cultivos. Se observaron diferencias significativas para densidad poblacional de bacterias con respecto a tejido, con mayores valores en raíz ( $\left.4 \times 10^{11} \mathrm{~g} / \mathrm{raí} \mathrm{z}\right)$, seguida de tallo $\left(3 \times 10^{10} \mathrm{~g} / \mathrm{tallo}\right)$, hoja ( $\left.5 \times 10^{9} \mathrm{~g} / \mathrm{hoja}\right)$,

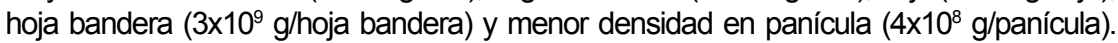
Los resultados de la identificación con kit API20E confirmaron la presencia de la bacteria endófita Burkholderia cepaceae y la bacteria rizosférica Pseudomona fluorescens con capacidad de tolerar diferentes concentraciones de $\mathrm{Cd}$, fijar nitrógeno, solubilizar fosfatos y producir sideróforos. 


\section{Introducción}

Existe una gran variedad de contaminantes ambientales, según su naturaleza y origen, tal es el caso de los metales pesados los cuales ejercen efectos dañinos sobre la biota y ocasionan un desequilibrio en los ecosistemas debido a su alta toxicidad y persistencia. Los suelos contaminados con metales pesados tóxicos, originan riesgo para la salud de los animales y los humanos, que consumen alimentos provenientes de plantas expuestas a altas concentraciones del metal pesado.

El Cd es un elemento no esencial y poco abundante en la corteza terrestre y a bajas concentraciones puede ser tóxico para todos los organismos vivos (WEISBERG et al., 2003). La contaminación ambiental por $\mathrm{Cd}$ ha aumentado como consecuencia del incremento de la actividad industrial que ha tenido lugar a finales del siglo $X X$ y principios del siglo XXI, afectando de forma progresiva a los diferentes ecosistemas y a la salud pública (SHENG et al., 2008). Los efectos tóxicos del Cd sobre las plantas, han sido ampliamente estudiados, sin embargo los mecanismos de su toxicidad aún no se conocen completamente. En general el Cd interfiere en la entrada, transporte y utilización de elementos esenciales $(\mathrm{Ca}, \mathrm{Mg}$, $\mathrm{P}$ y K) y del agua, provocando desequilibrios nutricionales e hídricos en la planta. Este deterioro ambiental ocasionado por los metales pesados se fundamenta en su alta toxicidad, lo cual se agranda por su marcada persistencia en los ecosistemas y bioacumulación en los organismos, puesto que son compuestos no biodegradables (GUERRA et al., 2014).

Esta contaminación mediada por metales pesados surge como resultado de la presión antrópica que genera el ser humano sobre los ecosistemas. Destacándose las actividades industriales y la agricultura (CAÑIZARES, 2000). Esta afectación al ambiente se intensifica en zonas de alta presión antropogénica, y la presencia de estos metales en los diferentes componentes aire, suelo y agua. Aunque concentraciones mínimas, generan grandes problemas a los seres vivos por su bioacumulación a lo largo de la cadena alimentaria (DI TOPPI et al., 1999).
En respuesta a toda esta problemática ambiental SHENG et al., (2008) establece que la fitorremediación trae consigo grandes beneficios en contraposición a la tecnología tradicional de acumular metales pesados del suelo. Tales ventajas son su bajo costo e insignificante impacto para los seres humano y los ecosistemas. Sin embargo, el lento y poco crecimiento de la biomasa vegetal limita su eficiencia. Como consecuencia se han explorado otras posibilidades que buscan optimizar este proceso.

Para dar respuesta a esta necesidad se ha mejorado la biomasa de plantas acumuladoras utilizando bacterias endófitas que promuevan el crecimiento vegetal, mediante la síntesis AIA, sideróforos y ACC desaminasa, son capaces de estimular el crecimiento de la planta, reducir el nivel de etileno por consumo de ACC. Es por eso que una mejor comprensión de las características de las bacterias endófitas resistentes a metales pesados es un requisito previo fundamental para el desarrollo de eficaces procesos de fitorremediación de suelos contaminados con metales pesados. Estos microorganismos endófitos resultan ser benéficos, se encuentran en los tejidos internos de las plantas sin generarles ningún tipo de afectación negativa, estos tienen la capacidad de desencadenar cambios fisiológicos que promueven el crecimiento y desarrollo de las plantas (PÉREZ Y CHAMORRO, 2013).

En los últimos años, el uso de bacterias endófitas resistentes, en la fitorremediación de metales pesados en suelos contaminados, ha adquirido mucha importancia, debido a que presentan la capacidad de tomar esos metales y utilizarlos como fuente de carbono (SUN et al., 2010). Esto indica que las bacterias endófitas han adquirido la capacidad de ser resistentes a altas concentraciones de metales pesados y que pueden conferir a la planta mayor tolerancia al estrés ocasionado por estos contaminantes.

Entre los microorganismos que intervienen en la fitorremediación de metales pesados, las bacterias de la rizósfera merecen especial atención, porque pueden facilitar el proceso de fitorremediación mediante el cambio de la biodisponibilidad de los metales a través de la alteración del pH del suelo, la liberación de agentes quelantes como 
por ejemplo ácidos orgánicos y sideróforos entre otros, y reacciones de oxidación/reducción (MA $Y$ et al., 2011).

La rizósfera proporciona un microambiente complejo y dinámico en el que microorganismos, en asociación con las raíces, forman comunidades únicas que tienen un potencial considerable para la promoción del crecimiento de plantas y la detoxificación de compuestos de desechos peligrosos (BELIMOV et al., 2005).

En este trabajo se plantea la evaluación in vitro de la capacidad de bacterias endófitas aisladas de diferentes tejidos de variedades de arroz comercial y de bacterias rizosfericas con habilidad de resistir cadmio a diferentes concentraciones.

\section{Materiales y Métodos}

Área de muestreo. El muestreo se realizó en el segundo semestre del 2016, en lotes cultivados con variedades comerciales de arroz F67 y F2000, sembradas en los municipios Nechí (Antioquía) y Achí (Bolívar).

Muestreo. Los muestreos se realizaron de forma aleatoria en forma de zig-zag, colectando en cada sitio 10 plantas completas (incluyendo raíces, macollas y hojas), también se tomaron 10 muestras de suelo rizosférico y muestras de suelo profundo. Las muestras fueron identificadas con la variedad respectiva y fecha de colecta. Estas fueron almacenadas y conservadas para su transporte al Laboratorio de Investigaciones Microbiológicas de la Universidad de Sucre y procesadas dentro de las siguientes 24 horas después de colectadas.

Aislamiento de bacterias endófitas de variedades de cultivos de arroz comercial. Las plantas colectadas de cada variedad de arroz fueron sometidas a un proceso de desinfección superficial. Raíces, macollas y hojas de cada planta fueron lavadas con agua estéril y cortadas en segmentos de un $1 \mathrm{~cm}$ aproximadamente. El proceso de desinfección superficial para cada tejido fue realizado de acuerdo con la metodología recomendada por PÉREZ et al., (2010). Después del proceso de desinfección, cada tejido se depositó en un plato de porcelana y se maceró con nitrógeno líquido hasta formar una muestra homogénea. De cada homogenizado se prepararon diluciones seriadas de $10^{-1}$ hasta $10^{-8}$, de las cuales se tomaron alícuotas de $0,1 \mathrm{ml}$ que fueron depositadas sobre la superficie del medio de cultivo agar R2A e incubadas a $32{ }^{\circ} \mathrm{C}$ por 72 horas. La densidad poblacional de bacterias por tejido (UFC/g de tejido) fue determinada mediante el conteo directo de colonias sobre la superficie de las placas con agar. Durante el conteo se observaron y seleccionaron aquellas colonias que se diferenciaban en cuanto a forma, textura, color y tamaño (PÉREZ et al., 2014).

Aislamiento de bacterias rizosféricas y de suelo profundo de variedades de cultivos de arroz comercial. Para el procesamiento de las diferentes muestras de suelo en el laboratorio se tomaron $10 \mathrm{~g}$ de cada muestra los cuales se mezclaron en agua peptonada estéril, se dejaron en agitación por 8 horas para estimular el crecimiento bacteriano. Se realizaron diluciones seriadas de $10^{-3}$ hasta $10^{-8}$ de las cuales se tomaron alícuotas de $1000 \mu \mathrm{l}$ que fueron depositadas sobre la superficie del medio de cultivo agar nutritivo e incubadas a $32^{\circ} \mathrm{C}$ por 7 días para su crecimiento. La densidad poblacional de bacterias por gramo de suelo fue determinada mediante el conteo directo de colonias sobre la superficie de las placas con agar. Durante el conteo se observaron y seleccionaron aquellas colonias que se diferenciaban en cuanto a forma, textura, color y tamaño (PÉREZ et al., 2014).

Evaluación in vitro de la resistencia a Cd de bacterias endófitas, bacterias rizosféricas y de suelo profundo. La evaluación in vitro de la resistencia de bacterias a diferentes concentraciones de Cadmio se realizó en medio mínimo tris-MMT (RATHNAYAKE et al., 2013) y se utilizó $\mathrm{CdCl}_{2}$ como fuente del metal pesado. La concentración inicial de Cd utilizada en el presente estudio fue de $10 \mathrm{ppm}$ y a partir de estase prepararon concentraciones del metal hasta 2500 ppm. Alícuotas de suspensiones de bacterias endófitas en fase logarítmica fueron inoculadas sobre el medio MMT. Como control se utilizó medio $\mathrm{MMT} \sin \mathrm{CdCl}_{2}$. El experimento se realizó por triplicado, el cual se incubó en agitación a 150 rpm y $32{ }^{\circ} \mathrm{C}$ por 120 horas (ZHANG et al., 2011). 
El crecimiento de las bacterias fue determinado mediante turbidimetría a $600 \mathrm{~nm}$ cada hora por cuatro días.

Evaluación cualitativa de la promoción de crecimiento de bacterias resistentes a $\mathrm{Cd}$. Los aislados que mostraron resistencia a $\mathrm{Cd}$ fueron utilizados para evaluar cualitativamente in vitro la capacidad de fijación biológica de nitrógeno, solubilización de fosfato y producción de sideróforos. La evaluación cualitativa de la fijación biológica de los aislamientos se realizó por la metodología propuesta por PÉREZ et al., (2014) en medio selectivo agar ASHBY. Cada uno de los morfotipos fueron sembrados en forma directa sobre la superficie del medio e incubados a $28^{\circ} \mathrm{C}$ por 72 horas. Después de este tiempo, se seleccionaron los morfotipos que fueron capaces de crecer en el medio, indicando la presencia de aquellas bacterias que poseen el sistema enzimático que les permite reducir el nitrógeno atmosférico y utilizarlo en su metabolismo. Para la evaluación cualitativa de la solubilización de fosfato de los aislamientos, se realizó, siguiendo la metodología propuesta por PÉREZ et al., (2014), sobre medio NBRIP con $\mathrm{Ca}_{3} \mathrm{PO}_{4}$ como fuente de fósforo insoluble a $\mathrm{pH}$ 7. Cada morfotipo fue inoculado sobre la superficie del medio e incubado a $28{ }^{\circ} \mathrm{C}$ por 72 horas. La observación cualitativa de los aislados se determinó por observación de la formación de halo transparente visible alrededor y debajo de la colonia.

La capacidad de producción de sideróforos se efectuó en medio cromo azurol-S (CAS) propuesto por SCHWYN y NEILANDS (1987). Para ello se disolvió $60,5 \mathrm{mg}$ de CAS en $50 \mathrm{ml}$ de agua destilada, lo anterior se combinó con $10 \mathrm{ml}$ de una solución de hierro (III) (1 mM de FeCl3.6 H2O y $10 \mathrm{mM}$ de $\mathrm{HCl}$ ). Bajo agitación, esta solución se mezcló con 72,9 mg de HDTMA disuelto en $40 \mathrm{ml}$ de agua. El líquido azul resultante se esterilizó a $121^{\circ} \mathrm{C}$ por 15 minutos. En otro recipiente también se esterilizará una mezcla de $750 \mathrm{ml}$ de agua, 15 gr de agar, 30,24 g de pipes, y $12 \mathrm{~g}$ de una solución $50 \%(\mathrm{w} / \mathrm{w})$ de $\mathrm{NaOH}$ para alcanzar un $\mathrm{pH}$ de 6,8 . Al medio se le agregaran $4 \mathrm{~g}$ de glucosa como fuente de carbono. Las cepas se incuban durante 7 días a $30^{\circ} \mathrm{C}$. La habilidad de la bacteria para producir sideróforos se evidencia por la formación de un halo.
Identificación de bacterias Cd-resistentes con actividad promotora de crecimiento vegetal. Las bacterias con actividad positiva para fijación biológica de nitrógeno, solubilización de fosfatos y producción de sideróforos, se identificaron por kit de pruebas bioquímicas API 20 E y 20 NE. La batería de pruebas API 20 E y API $20 \mathrm{NE}$ es un sistema de identificación rápida para bacterias de la familia Enterobacteria y otras bacterias Gram-negativas no entéricas, consta de 21 tests bioquímicos estandarizados y miniaturizados, y una base de datos. Este sistema presenta las ventajas de ser rápido, eficaz y de permitir realizar numerosas pruebas a la vez.

Análisis estadístico. El análisis de varianza se realizó por ANOVA multifactorial para determinar las diferencias entre densidad poblacional (UFC/g de tejido) de bacterias endófitas en función a variedad y tipo de tejido, como también de suelo rizosférico y suelo profundo. Se utilizó la prueba múltiple de rango (Tukey) para determinar si hubo diferencias entre las densidades poblacionales de bacterias en (UFC/g de tejidos) aisladas.

\section{Resultados y Discusión}

Aislamiento de bacterias endófitas y rizosféricas. Un total de 70 aislados de bacterias endófitas fueron obtenidos de las variedades de arroz F67 y F2000. El análisis de varianza mostró diferencias altamente significativas de la densidad poblacional en función a tipo de tejido y variedad de arroz analizada. La prueba múltiple de rangos de acuerdo con la media estándar de cada tejido y variedad analizada, mostró que la mayor densidad poblacional se observó en la raíz $\left(4 \times 10^{11}\right)$, seguida de tallo $\left(3 \times 10^{10}\right)$, hoja $\left(5 \times 10^{9}\right)$, hoja bandera $\left(3 \times 10^{9}\right)$ y panícula $\left(4 \times 10^{8}\right)$, respectivamente (Figura 1$)$.

La densidad poblacional de bacterias endófitas fue variable y pudo ser afectada por diversos factores como: época del año, el tipo de tejido, especie, variedad de plantas (MOCALI et al., 2003) y la interacción de las bacterias endófitas con otros microorganismos benéficos (ARAUJO et al., 2002). 


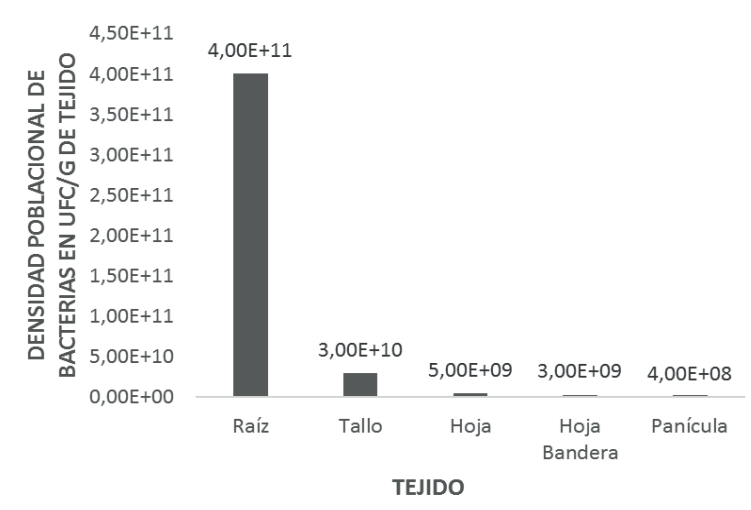

Figura 1. Resultados de prueba múltiple de rangos aplicados a la densidad poblacional de bacterias endófitas en función del tejido

Trabajos realizados por MANO et al., (2006) sobre densidad poblacional de bacterias endófitas cultivables en semillas de arroz, encontraron poblaciones de $10^{2}$ a $10^{6} \mathrm{UFC} / \mathrm{g}$ de peso fresco. Además, estos autores reportaron variación en la cantidad de estas bacterias con respecto al tipo de tejido analizado. Se ha reportado presencia de bacterias endófitas en semilla, raíz, macollas, hoja y hoja bandera de diferentes variedades de arroz (HIRONOBU y HISAU, 2008). Estudios acerca de poblaciones de bacterias endófitas sobre 2.400 segmentos de plantas de arroz cultivadas en el sureste de la India, demostraron que la tasa de colonización de tejidos por bacterias endófitas varió según la época del año (SHANKAR et al., 2009). Trabajos realizados de la densidad poblacional de bacterias endófitas, asociadas a diferentes especies vegetales, concluyeron que la presencia de estas bacterias es altamente variable; esta variación dependió de la especie de bacteria y el genotipo de la planta hospedera, además del estado de desarrollo de la planta, la densidad del inóculo y las condiciones ambientales PILLAY y NORWARK (1997).

De acuerdo a los resultados obtenidos en la densidad poblacional de bacterias rizosféricas y de suelo profundo se determinaron un total de 93 aislados de bacterias. La prueba de rango múltiple mostró diferencias para densidad poblacional de bacterias aisladas de suelo y suelo rizosférico, mostrando valores de $3.2 \times 10^{10}$ y $4.5 \times 10^{12}$. respectivamente.

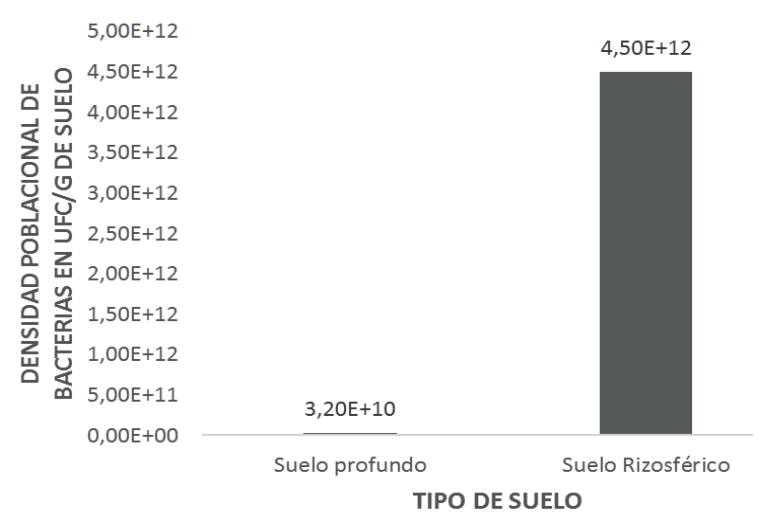

Figura 2. Resultados de prueba múltiple de rangos aplicados a la densidad poblacional de bacterias en función del tejido al tipo de suelo

A la fecha no existen reportes en la bibliografía especializada sobre la comparación de bacterias tanto en suelos profundos como en rizosféricos, razón por la cual estos resultados se convierten en pioneros de futuras investigaciones. Por lo tanto, se realizaran estudios posteriores para determinar con mayor eficacia estas densidades poblacionales de bacterias en otros tipos de suelos.

Prueba in vitro de resistencia a Cd de bacterias
endófitas, de suelo profundo y rizosféricas. Los resultados mostraron que de los 163 , solo dos morfotipos, crecieron sobre las diferentes concentraciones de Cadmio. Los resultados de la prueba in vitro de resistencia mostraron los aislados M1H1 (M: Muestra 1; H: Hoja 1) y M6-2 (M6: Muestra 6; morfotipo 2) con diferentes patrones de crecimiento donde la bacteria endófita $\mathrm{M} 1 \mathrm{H} 1$, mostró crecimiento hasta 400 ppm ó 0,4 $\mathrm{g} / \mathrm{l}$ de $\mathrm{CdCl}_{2}$, mientras que la bacteria rizosférica M6-2 mostró crecimiento hasta 2500 ppm ó 2,5 $\mathrm{g} / \mathrm{L}$ de $\mathrm{CdCl}_{2}$ con respecto a los tratamientos controles. El mayor crecimiento observado a $600 \mathrm{~nm}$ fue de $\mathrm{M} 1 \mathrm{H} 1$ fue de $0,1 \mathrm{~g} / \mathrm{L}$ del metal, el cual se mantuvo hasta las 40 horas de iniciado el experimento. En la figura 3 se observa que a medida que se aumentaban los valores del metal pesado la bacteria endófita presentaba demoras en su adaptación y por ende en su crecimiento. 


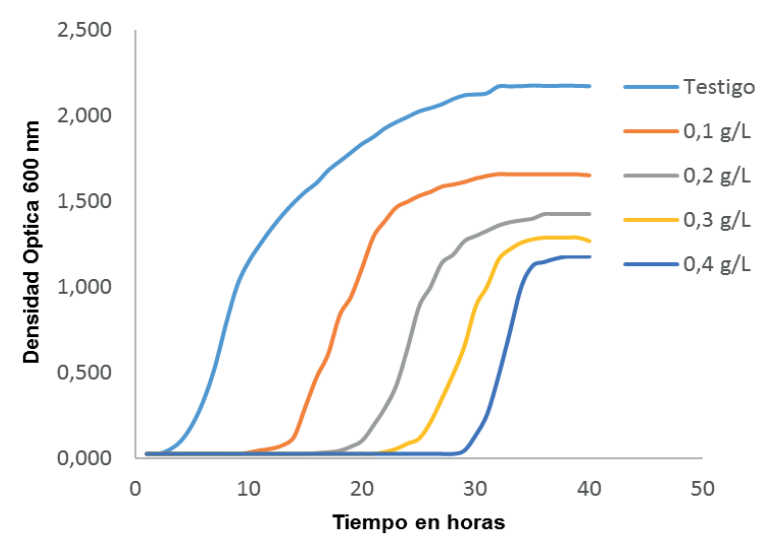

Figura 3. Prueba in vitro de resistencia a diferentes concentraciones de $\mathrm{Cd}$ en forma de $\mathrm{Cd} \mathrm{Cl}_{2}$ del aislado $\mathrm{M} 1 \mathrm{H} 1$, proveniente de variedades de arroz comercial.

Lo mismo se observa en la figura 4 donde muestra que la bacteria rizosférica M6-2 presenta un patrón de crecimiento alto en $0,5 \mathrm{~g} / \mathrm{L}$ del metal y a medida que se aumentaba la concentración de $\mathrm{CdCl}_{2}$ el crecimiento de la misma se veía afectado. El bajo crecimiento de los aislados, puede explicarse por los efectos de toxicidad del metal, que provocaron alteraciones en las características metabólicas y fisiológicas de las bacterias (KAMIKA y MOMBA, 2013).

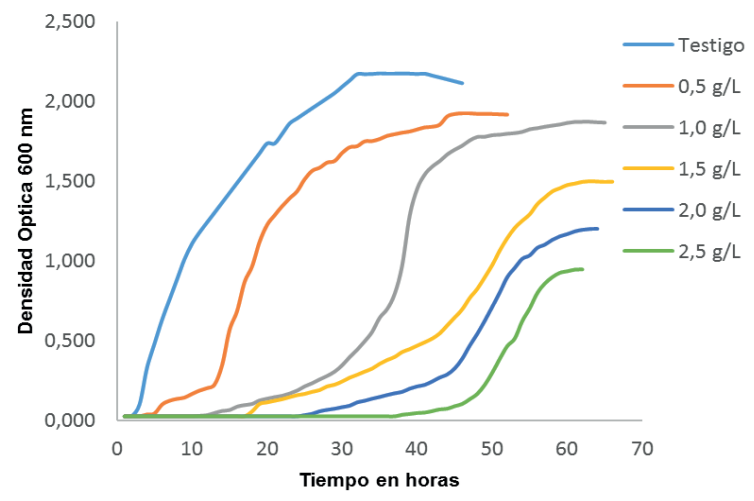

Figura 4. Prueba in vitro de resistencia a diferentes concentraciones de $\mathrm{Cd}$ en forma de $\mathrm{Cd} \mathrm{Cl}_{2}$ del aislado M6-2, proveniente de suelos rizosféricos de cultivos de arroz.

Estos resultados demuestran que a medida que se aumentó la concentración del metal no solo disminuyó la cantidad de células bacterianas, sino que también se retardó el crecimiento, necesitando más tiempo para que la bacteria se adaptara y recuperara su capacidad para crecer en un medio contaminado con $\mathrm{Cd}$, como lo demostraron trabajos similares realizados por KAMIKA y MOMBA (2013). Sin embargo, la interacción entre el metal y la bacteria puede ser un mecanismo clave que contribuye a la biodisponibilidad $y$ toxicidad del metal (KAMALAKANNAN y KRISHNAMOORTHY, 2006). Estudios posteriores determinarán que factores ecológicos in vitro pueden influir en el crecimiento y resistencia de bacterias endófitas a diferentes concentraciones de Cd.

\section{Actividad promotora de crecimiento vegetal} Actividad fijadora de nitrógeno. Los resultados obtenidos de la prueba de fijación de nitrógeno, mostró11 bacterias endófitas con esta actividad (M1H1; M1T4; 6P1; M1H4; M1H3; 1P6; AP1; AT3; $\mathrm{MH} 1 ;$ 7P10; 7P1), así mismo se observaron 8 bacterias rizosféricas con esta misma capacidad (M6-2; M6-6; M3R; M13R; M1-8R; M6-5; M10R; M2-11), (Figura 5).

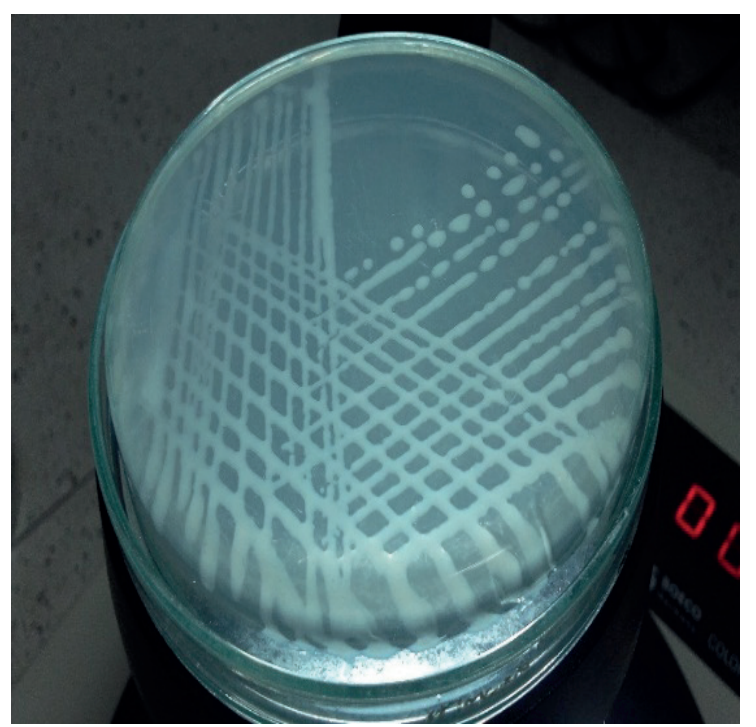

Figura 5. Actividad de fijación biológica de nitrógeno in vitro de bacterias endófitas aisladas de plantas de variedades de arroz comercial y bacterias rizosféricas de los municipios de Nechí (Antioquía) y Achí (Bolívar). Fuente: Chamorro, Ayubb, cerra

Las bacterias aeróbicas dependen fuertemente de las condiciones de humedad, oxígeno y materia orgánica, y las anaeróbicas son predominantes en suelos anegados donde existen las condiciones de humedad y materia orgánica, pero el suministro de oxígeno está restringido. La fijación biológica de nitrógeno en los suelos tropicales con las condiciones requeridas de humedad, temperatura 
y materia orgánica es generalmente alta. Se reporta que el número de bacterias fijadoras de nitrógeno es particularmente elevado en la zona adyacente a la raíz (rizósfera), debido a la liberación de compuestos orgánicos que le sirven como nutrimento (DUGAN, 2004).

Actividad solubilizadora de fosfato. Los resultados de la actividad in vitro de solubilización de fosfato, mostró 3 bacterias endófitas con esta actividad (M1H1: M1H4; M1H3), al igual que 6 bacterias rizosféricas (M6-2; M6-6; M3R; M13R; M1-8R; M6-5), (Figura 6). El fósforo aunque es uno de los principales macronutrientes esencial para cualquier organismo vivo, se encuentra poco disponible en especial para las plantas, debido a que la mayor parte del fósforo se encuentra en el suelo en forma mineral, lo cual lo hace insoluble y no disponible; solo las formas solubles de este, lo convierten en disponibles tanto para plantas como para microorganismos (BEHERA et al., 2014). Una de las características de las bacterias endófitas es la habilidad de incrementar la movilización del fosfato, por el desarrollo de mecanismos que permiten captar las formas de fosfato insoluble, liberarlo y haciéndolo disponible para la planta (RYAN et al., 2008).

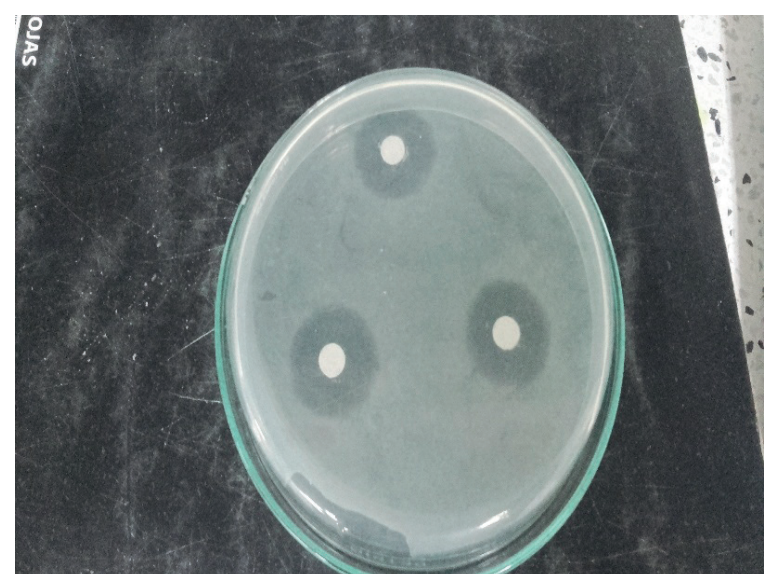

Figura 6. Actividad solubilizadora de fosfato in vitro de bacterias endófitas aisladas de plantas de variedades de arroz comercial y bacterias rizosféricas de los municipios de Nechí (Antioquía) y Achí (Bolívar). Fuente: Chamorro, Ayubb, cerra

Uno de los mecanismos que usan las bacterias para solubilizar fosfato es a través de ácidos orgánicos. La gran mayoría de los ácidos producidos por estas bacterias ya ha sido previamente identificados, entre ellos encontramos los ácidos málico, oxálico, citrato, gluconatos entre otros, los cuales forman complejos con fosfatos de aluminio, hierro o en este caso calcio, presentándose un aumento en cationes $(\mathrm{H}+)$ lo cual reduce el $\mathrm{pH}$ dándose, la liberación de fosfato disponible o soluble (JONES y OBURGER, 2011).

Producción de sideróforos. De acuerdo a los resultados se observaron 4 bacterias endófitas con la capacidad de producir sideróforos $(\mathrm{M} 1 \mathrm{H} ; 6 \mathrm{P} 1$; $\mathrm{M} 1 \mathrm{H} 4 ; \mathrm{MH} 1)$, al igual que 8 bacterias rizosféricas con esta misma actividad (M6-2; M6-6; M3R; M13R; M1-8R; M6-5; M10R; M2-11), (Figura 7).

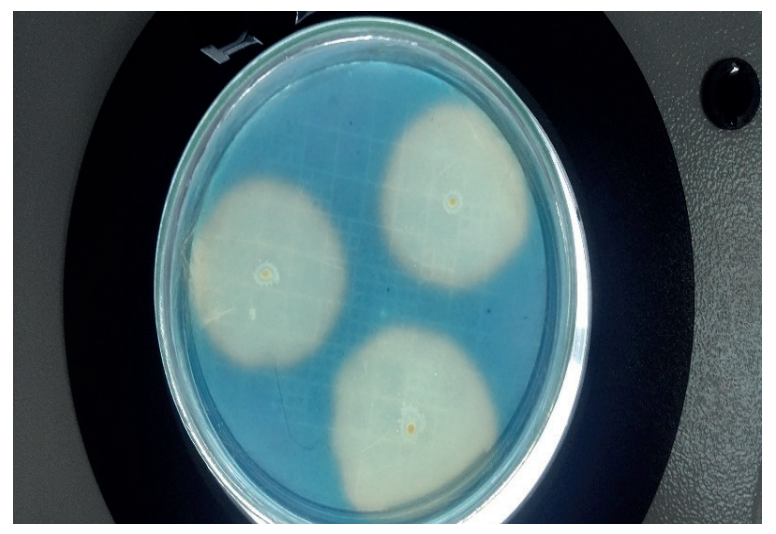

Figura 7. Actividad productora de sideróforos in vitro de bacterias endófitas aisladas de plantas de variedades de arroz comercial y bacterias rizosféricas de los municipios de Nechí (Antioquía) y Achí (Bolívar). Fuente: Chamorro, Ayubb, cerra

Las bacterias promotoras de crecimiento vegetal que poseen la capacidad de producir sideróforos secuestran el hierro al formar un complejo $\mathrm{Fe} 3+$ sideróforo, mediante un receptor específico localizado en la membrana bacteriana, lo cual ocasiona que este metal no se encuentre disponible para otros microorganismos que carezcan del sistema de asimilación específico para reconocer dicho complejo. De esta manera, al utilizar todo o la mayoría del hierro disponible en el suelo suprime o inhibe el crecimiento de otros microorganismos patógenos (o benéficos) presentes en la rizósfera (COMPANT et al., 2005). Las plantas no se ven afectadas por el secuestro de hierro por parte de las rizobacterias, ya que la mayoría de ellas son capaces de crecer en medios con concentraciones de $\mathrm{Fe} 3+$ mucho menores que 
los microorganismos (O SULLIVAN y O'GARA, 1992), además de que algunas son capaces de utilizar los complejos Fe3+-sideróforo bacterianos.

Identificación de bacterias resistentes a Cd. De acuerdo al sistema de identificación API 20E y $20 \mathrm{NE}$ se identificaron dos especies y/o grupo de bacterias aisladas siguiendo la metodología descrita, y presentaron actividad promotora de crecimiento. Se confirmó la identificación de Burkholderia cepaceae y Pseudomona fluorescens con capacidades de tolerar altas concentraciones de Cadmio y promoción de crecimiento vegetal. Entre los resultados obtenidos se identificó la bacteria Burkholderia cepaceae, como un aislado obtenido de la rizósfera. Es una bacteria gram negativa de forma bacilar y anaeróbica facultativa, capaz de solubilizar fósforo y estimular notablemente el crecimiento de las partes verdes y raíz de las plantas (RIERA, 2003). En los últimos años, esta especie adquiere vital importancia en estudios relacionados con la agricultura, debido fundamentalmente a la producción de una amplia gama de metabolitos activos, que influyen positivamente en el crecimiento y desarrollo saludable de las plantas. (BEVIVINO, 2000).

En este estudio se determinó el crecimiento ante la presencia de Cadmio que es un metal pesado y se evidenció su capacidad de promover el crecimiento vegetal. Estudios realizados por MADHAIYAN et al.; (2007), demostró que la bacteria Burkholderia sp reduce la acumulación de cadmio y plomo en raíces y brotes en plántulas de tomate como también del metal que está disponible en el suelo y estos es debido a la absorción y bioacumulación del metal por parte de la bacteria. (LODEWYCKX et al., 2001) encontró Burkholderia cepaceae como una bacteria endófita de Lupinus luteus el cual tiene la capacidad de resistir altas concentraciones de Niquel.

También en investigaciones realizadas por PÉREZ et al., (2016) demostraron la capacidad que tiene Burkholderia cepaceae de tolerar concentraciones elevadas del metal Plomo. Con lo anteriormente expuesto cabe destacar la importancia que tiene esta especie de bacteria en la biorremediación de sitios contaminados con metales pesados. Por otro lado esta bacteria ha presentado la capacidad de promover crecimiento vegetal como lo demuestra CABALLERO et al., (2007) donde establecen la presencia de esta bacteria como fijadora de nitrógeno, estudiando la rizósfera y el rizoplano en cultivos de tomate en México. Ellos determinaron su capacidad de fijar nitrógeno mediante la prueba de reducción de acetileno y la detección de los genes nifH. MOHAMMAD (1998), determinó bacterias del genero Burkholderia sp promotoras del crecimiento vegetal por su capacidad de solubilizar fosfatos.

Estudios realizados en cultivos de arroz han identificado una diversidad de poblaciones de especies de bacterias endófitas en rizósfera como en diferentes tejidos vegetales. En la rizósfera de esta especie vegetal principalmente se ha reportado el género de bacterias endófitas Pseudomonas, Burkholderia, Azetobacter y Bacillus (HERNANDEZ et al., 2004), como promotoras de crecimiento vegetal. Otros estudios in vitro sobre resistencia de bacterias endófitas a cadmio ( $C d)$ mostraron que especies de bacterias del grupo de Burkholderia sp. poseen la capacidad de solubilizar in vitro metales como $\mathrm{Pb}$ y $\mathrm{Cd}$ en diferentes concentraciones y de acumular estos dos metales en tejidos de plantas de maíz y tomate, y la subsecuente estimulación del crecimiento de estas plantas in vivo (CHUN et al., 2008).

El género de bacteria Burkholderia representa a un grupo de dieciocho especies relacionadas que actualmente tienen interés por la extraordinaria versatilidad como patógenos de plantas, saprófitos, agentes de biocontrol, biorremediación y patógeno de humanos. Estas bacterias abundan naturalmente en el suelo, agua y en la superficie de distintas especies vegetales, poseen capacidad de metabolizar un amplio rango de compuestos orgánicos como fuente de carbono y energía. Una cualidad que ha despertado interés en este grupo de bacterias es su uso en biorremediación de suelos y agua subterránea contaminadas con hidrocarburos y herbicidas (ORELIO et al., 2014).

Otra especie identificada en este estudio fue la bacteria Pseudomona fluorescens, Las bacterias del género Pseudomona presentan gran capacidad para utilizar diversidad de nutrientes, razón por la que se explica su ubicuidad. Su actividad enzimática las convierte en un grupo de microorganismos importante, debido a que son responsables de la degradación aeróbica 
de muchos compuestos en diversos ecosistemas (NAVA, 2012). De acuerdo a la literatura no existen evidencias que demuestren a esta bacteria como degradadora de Cadmio en plantas de arroz. Sin embargo, muchos estudios se han realizado en cuanto al género Pseudomona en la degradación de metales pesados ya que poseen la habilidad de utilizar diversos sustratos.

Algunos estudios han demostrado Pseudomonas fluorescens como degradadora de naftaleno y fenantreno, ventaja que tiene frente a otras Pseudomonas, que solo metabolizan naftaleno y asfaltenos (ROCKNE, 2000), también es de destacar que esta bacteria tiene la capacidad de sintetizar ramnolípidos cuando se encuentra en la fase estacionaria de su crecimiento, por tal razón esto solo se puede realizar en la primera fase del proceso de biorremediación y contribuyendo así con la movilización y solubilización de los contaminantes durante la fase siguiente de mineralización. Al mismo tiempo que pueden transformarse bajo microcosmos en el suelo con un tratamiento físico o químico especifico (DEMANECHE, 2001).

También en este estudio se determinó la capacidad que tiene Pseudomonas fluorescens en la promoción del crecimiento vegetal, mediante las pruebas de fijación de nitrógeno, solubilización de fosfato y producción de sideróforos. Una de las características de esta bacteria es su alta capacidad de solubilizar fósforo orgánico e inorgánico del suelo. La bacteria produce ácidos orgánicos como ácido cítrico, ácido oxálico y ácido glucónico, que actúan sobre el pH; estos ácidos rompen las uniones entre los cationes $\left(\mathrm{Ca}^{2+}, \mathrm{Mg}^{2+}\right)$ unidos a las arcillas y los aniones fosfatos, liberando estos últimos a la solución del suelo, favoreciendo así la solubilización del fósforo inorgánico (ADHYA et al., 2015).

Por otra parte, la bacteria puede producir fosfatasas, que son enzimas hidrolasas (monoesterasas y diesterasas fosfóricas) que actúan sobre las uniones ésteres, liberando los grupos fosfatos de la materia orgánica a la solución del suelo. Ambas vías generan una mayor cantidad de fosfato para ser absorbido por las raíces de las plantas (LÓPEZ et al., 2014). Lo anterior ha permitido el desarrollo de productos solubilizadores de fósforo, los cuales se emplean en cultivos agrícolas como trigo, arroz y maíz, para poner a disposición de las plantas el fósforo del suelo (GONZÁLEZ, 2006). También se destaca por parte de Pseudomonas fluorescens, la producción de sideróforos como las pioverdinas y quinolabactinas, implicados en la actividad de promoción de crecimiento y biocontrol en plantas (MOSSIALOS et al., 2000), como se evidencia en trabajos realizados por Pérez et al., 2000, que evaluó el papel de los sideróforos de esta bacteria tanto en el crecimiento como en la reducción de daños por patógenos en plantaciones de Lotus corniculatus. También existen otros estudios donde demuestran que Pseudomonas fluorescens (VIKRAM, 2007), tienen la capacidad de solubilizar fosfatos a partir de fuentes inorgánicas insolubles (ALARCÓN y FERRERA, 2012).

En diferentes estudios, se ha determinado el efecto positivo de bacterias del género Pseudomonas sp. en Lactuca sativa sobre la promoción de crecimiento de esta especie (SOMEYA et al., 2008). De acuerdo a las investigaciones realizadas por SANCHEZ et al., (2014), demuestran que Pseudomonas fluorescens es una bacteria que tiene la capacidad de producir índoles, sideróforos y además solubilizar fósforo de fuentes muy poco solubles como la roca fosfórica y estimuló el crecimiento en las plantas de Lactuca sativa cultivar White Boston.

\section{Conclusiones}

Los resultados obtenidos en el presente estudio muestran a las bacterias Burkholderia cepaceae y Pseudomonas fluorescens, como bacterias capaces de tolerar altas concentraciones de Cadmio, como también promotoras de crecimiento vegetal en plantaciones de arroz. Esto nos permite concluir que estos morfotipos bacterianos se convierten en una alternativa biológica en la remoción de metales en ambientes contaminados con los mismos.

Estas bacterias se consideran que podrían convertirse en posibles recursos biológicos para ser utilizadas para mejorar el crecimiento en cultivo de arroz y consecuentemente incrementar la toma y resistencia de $\mathrm{Cd}$ en estas variedades.

Agradecimientos. Los autores agradecen a la Universidad de Sucre por toda su colaboración en la ejecución de la investigación, como también a la Federación Nacional de arroceros (FEDEARROZ) por el suministro de las variedades de arroz. 


\section{Referencias.}

ADHYA, T.K.; KUMAR, N.; REDDY, G.; PODILE, A.R.; BEE, H.; SAMANTARAY, B. 2015. Microbial Mobilization of Soil of Phosphorus and Sustainable P Management in Agricultural Soils. Current Science. 108:1280-1287.

ALARCÓN, A.; FERRERA C.R. 2012. Biofertilizantes: Importancia y utilización en la agricultura. Revista Mexicana de Ciencias Agrícolas. 26 (2): 191-203.

ARAUJO, W. L.; MARCON, W.J.; MACCHERONI, E.J.; VAN, J.W.; AZEVEDO, J.L. 2002. Diversity of endophytic bacterial populations and their interaction with Xylella fastidiosa in citrus plants. Applied Environmental Microbiology. 68:4906-4914.

BEHERA, B.; SINGDEVSACHAN, S.; MISHRA, R.; DUTTA, S.; THATOI, H. 2014. Diversity, mechanism and biotechnology of phosphate solubilising microorganism in mangrove, a review. Biocatalysis and Agricultural Biotechnology. 3(2): 97-110

BELIMOV, A.; HONTZEAS, N.; SAFRONOVA, V.; DEMCHINSKAYA, S.; PILUZZA, G.; BULLITTA, S.; GLICK, B. 2005. Cadmium tolerant plant growth-promoting bacteria associated with the roots of Indian mustard (Brassica juncea LC zern.). Soil Biology \& Biochemistry. 37:241-50.

BEVIVINO, A.; DAMALSTRI, C.; TABACCHIONI, S.; CHIARINI, L. 2000. Efficacy of Burkholderia cepacia MCL 7 in disease suppression and growth promotion of maize. Biology and Fertility of Soils. 31(4): 225-231.

CABALLERO M.J.; ONOFRE L.J.; ESTRADA, D.P.; MARTINEZ, A.L. 2007. The tomato rhizosphere, an environment rich in nitrógen-fixing Burkholderia species with capabilities of interest for agriculture and biorremediation. Applied Environmental Microbiology. 73(3): 5308-5319.

CAÑIZARES, R. 2000. Bioabsorción de metales pesados mediante el uso de biomasa microbiana. Revista Latinoamericana de Microbiología 42:131- 143.

CHUN YU, J.; XIA-FANG, S.; MENG, Q.; QING-YA, W. 2008. Isolation and characterization of a heavy metal resistant Burkholderia sp. from heavy metal contaminated paddy feld soil and its potential in promoting plant growth and heavy metal accumulation in metal-polluted soil. Chemosphere. 72(2):57-64.

COMPANT, S.; DUFFY, B.; NOWAK, J.; CLEMENT, C.; BARKA, E.A. 2005. Use of plant growth-promoting bacteria for biocontrol of plant diseases: principles, mechanisms of action, and future prospects. Applied Environmental Microbiology. 71:4951-4959.

DEMANECHE, S.; KAY, E.; GOURBIERE, F.; SIMONET, P. 2001. Natural transformation of Pseudomonas fluorescens and Agrobacterium tumefaciens in soil. Applied and Environmental Microbiology. 67 (6): 2617-2621.

DI TOPPI, L.S.; GABBRIELLI, R. 1999. Response to cadmium in higher plants. Environmental and Experimental Botany. 41: 105- 130.

DUGAN, M. 2004. Field Training Manual For Laboratory Analysts. Disponible en: www.home.alltel.net/ mikeric/chap 10up/chapter 10 Nitrogen. Htm.

GUERRA, B.; SANDOVAL, A.; MANRIQUE, L.; BARRERA, S. 2014. Ensayos preliminares in vitro de bioabsorción de cadmio por cepas fúngicas nativas de suelos contaminados. Innovaciencia 2014; 2 (1): $53-58$ 
GONZALEZ, A.G. 2006. El fósforo y los microorganismos del suelo, Departamento Desarrollo, Rizobacter Argentina. S.A.

HERNÁNDEZ, A.; MEDINA, N.; QUIÑÓNEZ, M.; HOFTE, M.; HENDRICH, M.; HERNÁNDEZ, A. N. 2004. Strain identification of Burkholderia cepacia and Pseudomonas fluorescens associated to maize crop by pholyphasic taxonomi. Revista Mexicana de Fitopatología. 22(2): 198-207

HIRONOBU, M.; HISAU M. 2008. Endophytic bacteria in the plant rice. Microbes Environmental. 23:19-117.

JONES, D. L.; OBURGER, E. 2011. Solubilization of phosphorus by soil microorganisms. Phosphorus in Action (pp. 169-198): Springer.

KAMALAKANNAN, S.; KRISHNAMOORTHY R. 2006. Isolation of mercury resistant bacteria and influence of abiotic factors on bioavailability of mercury -a case study in Pulicat Lake north of Chennai, south east India. Science of the Total Environment. 367:341-353

KAMIKA, I.; MOMBA, M.N. 2013. Assessing the resistance and bioremediation ability of selected bacterial and protozoan species to heavy metals in metal rich industrial wastewater. BMC Microbiology. 10(4):13- 28

LODEWYCKX, C.; TAGHAVI, S.; MERGEAY, M.; VANGRONSVELD, J.; CLIJSTERS, H.; VAN DER LELIE, D. 2001. The effect of recombinant heavy metal resistant endophytic bacteria in heavy metal uptake by their host plant. International Journal of Phytoremediation. 3:173- 187

LÓPEZ, D.B.S.; HOYOS, A.M.G.; PERDOMO, F.A.R.; BUITRAGO, R.R.B. 2014. Efecto de rizobacterias promotoras de crecimiento vegetal solubilizadoras de fosfato en Lactuca sativa cultivar White Boston. Revista Colombiana de Biotecnología. 16(2): 122-128.

MA, Y.; RAJKUMAR, M.; LUO, Y.; FREITAS, H. 2011. Inoculation of endophytic bacteria on host and non-host plants effects on plant growth and Ni uptake. Journal of Hazardous Materials. 196:230-7.

MADHAIYAN, M.; POONGUZHALI, S.; SA, T. 2007. Metal tolerating methylotrophic bacteria reduces nickel and cadmium toxicity and promotes plant growth of tomato (Lycopersicon esculentum L.). Chemosphere. 69: $220-228$

MANO, H.; TANAKA, F.; WATANABE, A.; KAGA, H.; OKUNISHI, S.; MORISAKI, H. 2006. Culturable surface and endophytic bacterial flora of the maturing seeds of rice plants (Oryza sativa) cultivated in a paddy feld. Microbes Environmental. 21:86-100

MOCALI, S.; BERTELLI, E.; MENGONI A.; SFALANGA, A.; VILIANI, F.; CACIOTTI, A \& TEGLI S.G. 2003. Fluctuation of bacteria isolated from elm tissues during different seasons and from different plant organs. Research in Microbiology. 154:105-114

MOHAMMAD, G.; PRASAD, R. 1998. Influence of microbial fertilizers on biomass accumulation in polypotted Eucalyptus calmadulensis. Journal of Tropical Ecology. 4:74-7.

MOSSIALOS, A.; MEYER, J.M.; BUDZIKIEWICZ, H.; WOLFF, U.; KOEDAM, N.; BAYSSE, C.; ANJAIAH, V.; CORNELIS, P. 2000. Quinolobactin, a New Siderophore of Pseudomonas fluorescens ATCC 17400, the production of wich is repressed by the cognate Pyoverdine. Applied and environmental Microbiology. 66(2): 487-492.

NAVA, P.E.; GARCÍA, G.C.; CAMACHO, B.J.R.; VÁZQUEZ, M.E.L. 2012. Bioplaguicidas: una opción para el control biológico de plagas. Ra Ximhai. 8(3): 17-29. 
ORELIO, C.C.; BEIBOER, H.W.; MORSINK, M.C.; TEKTAS, S.; DEKTER, H.E.; VAN LEEUWEN, W.B. 2014. Comparison of Raman spectroscopy and two molecular diagnostic methods for Burkholderia cepacia complex species identification. Journal Microbiology Methods 107:126-132.

O'SULLIVAN, D.J.; O'GARA, F.1992. Traits of fluorescent Pseudomonas spp. involved in suppression of plant root pathogens. Microbiology Reviews. 56:662-676.

PÉREZ, C.; DE LA FUENTE, L.; ARIAS, A.; ALTIER, N. 2000. Uso de Pseudomonas fluorescens nativas para el control de enfermedades de implantación en Lotus corniculatus L. Agrociencia. 4(1):41-47.

PÉREZ, C.; ROJAS, J.; FUENTES, C. 2010. Diversidad de bacterias totales y endófitas asociadas a raíces del pasto Bothriochloa pertusa (L)A. Camus. Revista Colombiana de Ciencia Animal. 2(1): 58-72.

PEREZ, A.; CHAMORRO, L. 2013. Endophytic bacteria: a new field of research for development of agricultural sector. Revista Colombiana de ciencia Animal. 5(2):439-462.

PÉREZ, C.; TUBERQUIA, A.; AMELL, D. 2014. Actividad in vitro de bacterias endófitas fijadoras de nitrógeno y solubilizadoras de fosfatos. Revista Agronomía. Mesoamericana. 25(2):213-223.

PÉREZ, A.; MARTíNEZ, D.; BARRAZA, Z.; MARRUGO, J. 2016. Bacterias endófitas asociadas a los géneros Cyperus y paspalum en suelos contaminados con mercurio. Revista U.D.C.A Actualidades \& Divulgación Científica. 19(1): 67-76,

PILLAY, V.K.; NORWARK, J. 1997. Inoculam, density, temperature, and genotype effect on in vitro growth promotion and epiphytic and endophytic colonization of tomato (Lycopersicon esculentum L.), seeding inoculated with a pseudomonal bacterium. Canadian Journal of Microbiology. 43:354-61.

RATHNAYAKE, I.V.N.; MALLAVARAPU, M.; KRISHNAMURTI, G.S.R.; BOLAN N.S.; NAIDU R. 2013. Heavy metal toxicity to bacteria - Are the existing growth media accurate enough to determine heavy metal toxicity. Chemosphere 90:1195-1200.

ROCKNE, K.; SANFORD, J.; SANFORD, R.; BRIAN, P.; JAMES, T.; STALEYAND, S. 2000. Anaerobic naphthalene degradation by microbial pure cultures under nitrate-reducing conditions. Applied and Environmental Microbiology. 66: (4)1595-1601.

RIERA, M. C. 2003. Manejo de la biofertilización con hongos micorrízicos arbusculares y rizobacterias en secuencias de cultivos sobre suelo Ferralítico rojo. [Tesis en opción al grado de Doctor en Ciencias Agrícolas]. La Habana: Instituto Nacional de Ciencias Agrícolas. 120.

RYAN, R. P.; GERMAINE, K.; FRANKS, A.; RYAN, D. J.; DOWLING, D. N. 2008. Bacterial endophytes: recent developments and applications. FEMS Microbiology Letters. 278(1): 1-9.

SÁNCHEZ, D.B.; GARCÍA, A.M.; ROMERO, F.A.; BONILLA, R.R. 2014. Efecto de rizobacterias promotoras de crecimiento vegetal solubilizadoras de fosfato en Lactuca sativa cultivar White Boston. Revista Colombiana de Biotecnología. 16(2): 122-128.

SCHWYN, B.; NEILANDS, J.B. 1987.Universal chemical assay for the detection and determination of siderophores. Analytical Biochemistry. 160: 47-56.

SHANKAR, B.; SHASHIKALA, J.; KRISHNAMURTHY, Y.L. 2009. Study on the diversity of endophytic communities from rice (Oryza sativa L.) and their antagonistic activities in vitro. Microbiology Research. 164:290-6 
SHENG, X.; XIA, J.; JIANG, C.; HE, L.; QIAN, M. 2008. Characterization of heavy metal-resistant endophytic bacteria from rape (Brassica napus) roots and their potential in promoting the growth and lead accumulation of rape. Environmental Pollution. 156: 1164-1170.

SOMEYA, N.; TSUCHIYA, K.; SUGISAWA, S.; NOGUCHI, M; YOSHIDA, T. 2008. Growth Promotion of Lettuce (Lactuca sativa L.) by a Rhizobacterium Pseudomonas fluorscens Strain LRB3W1 under IronLimiting Condition. Environmental Control in Biology. 46(2):139-146.

SUN, L.N.; ZHANG, Y.F.; HE, L.Y.; CHEN, Z.J.; WANG, Q.Y.; QIAN, M. 2010. Genetic diversity and characterization of heavy metal-resistant-endophytic bacteria from two copper tolerant plant species on copper mine wasteland. Bioresource Technology 101:501-509

VIKRAM, A. 2007. Efficacy of phosphate solubilizing bacteria isolated from Vertisols on growth and yield parameters of sorghum. Research Journal of Microbiology. 2: 550-559.

WEISBERG, M.; JOSEPH, P.; HALE, B.; BEYERSMANN, D. 2003. Molecular and cellular mechanisms of cadmium carcinogenesis. Toxicology. 192: 95-110.

ZHANG, Y.F.; HE, L.Y;CHEN, Z.J.; ZHANG, W.H.; WANG, Q.Y.; QIAN, M.; SHENG, X.F. 2011. Characterization of leadresistant and ACC deaminase-producing endophytic bacteria and their potential in promoting lead accumulation of rape. Journal of Hazardous Materials. 186:1720-1725. 